\title{
The Influence of Quenchant Composition on Cooling Rate
}

\author{
Ljiljana PEDIŠI $\check{C}^{1)}$, Božidar MATIJEVIĆ ${ }^{2)}$ and \\ Jasminka MUNIĆ ${ }^{I)}$ \\ 1) Maziva-Zagreb Ltd, Member of INA Group, \\ Radnička cesta 175, HR-10000 Zagreb, \\ Republic of Croatia \\ 2) Sveučilište u Zagrebu, Fakultet strojarstva i \\ brodogradnje (University of Zagreb, Faculty \\ of Mechanical Engineering and Naval \\ Architecture), Ivana. Lucica 5, HR-10000 \\ Zagreb, Republic of Croatia
}

ljiljana.pedisic@ina.hr
Received (primljeno): 2009-09-10

Accepted (prihvaćeno): 2010-12-30
Preliminary note

Correct selection of quenching media decreases the risk of tensile stresses, and also cracking and workpiece distortion. High-performance quenching oil must have excellent oxidation and thermal resistance and low sludge formation, must be non-staining and have an elevated flash point and acceptable heat-transfer characteristics. The quenching media contain base oil and different types of additives according to application requirements. As the base oil, it is possible to use mineral oils, synthetic and natural oils separately or in combination. Mineral base oils are widely used because of their advantages in stability in comparison to natural oils, or lower prices in comparison to synthetic oils. There are numerous compounds available for use but, besides functional properties, the environmental and safety requirements have a strong influence on components selection. Based on that the barium additives must be replaced with less harmful compounds. Petroleum derivatives should be changed with renewable base stocks that are biodegradable, as the general trend in lubricant development. By changing the composition of quenching oils, base oils and additives, heat transfer characteristics are also changed. In this study the examination results of physical-chemical properties and also cooling characteristics of new quenching oils with different compositions are presented. Cooling curves for different compositions have been evaluated according to ISO 9950 standard.

\section{Utjecaj sastava sredstava za gašenje na brzinu ohlađivanja}

Prethodno priopćenje

Ispravnim odabirom sredstva za gašenje smanjuje se rizik od nastajanja napetosti kao i pojave pukotina i deformacija obratka. Visokovrijedna ulja za kaljenje moraju imati odlična svojstva otpornosti na oksidaciju i postojanost pri povišenoj temperaturi, niski stupanj stvaranja taloga, što više plamište i prihvatljiva svojstva prijenosa topline. Ulja za kaljenje sastoje se od baznog ulja i različitih vrsta aditiva prema zahtjevima primjene. Kao bazno ulje mogu se primijeniti mineralna ulja, sintetička i prirodna ulja kao i njihove mješavine. Mineralna ulja su u najširoj primjeni zbog bolje stabilnosti u odnosu na prirodna ulja ili zbog niže cijene u odnosu na sintetička ulja. Postoji cijeli niz tvari koje se mogu primijeniti, ali osim radnih svojstava, ekološki i sigurnosni zahtjevi imaju velik utjecaj na izbor sastava ulja za kaljenje. Temeljem toga aditivi na osnovi barija moraju se zamijeniti manje štetnim spojevima. Slijedom općenitog trenda razvitka maziva, mineralna bazna ulja treba zamijeniti baznim uljima iz obnovljivih izvora koja su biorazgradljiva. Promjenom sastava ulja za kaljenje, baznog ulja i aditiva, svojstva prijenosa topline također se mijenjaju. U ovome radu prikazani su rezultati ispitivanja fizikalno kemijskih svojstava a također i svojstva sposobnosti ohlađivanja novih ulja za kaljenje s različitim sastavima. Ispitivanim uljima za kaljenje snimljene su krivulje hlađenja prema normi ISO 9950.

\section{Introduction}

The heat treatment processes include annealing, hardening, stress relief, improving and surface hardening [1]. During metal heat treatment many different cooling and quenching media can be used. According to ISO 6743-14 standard, heat treatment- U [2], oils and similar products applied in the metal hardening process are divided into six groups identified by letter:

$\mathrm{H}=$ indicates a mineral oil type products

$\mathrm{A}=$ indicates an aqueous fluid, such as water or a polymer solution

$\mathrm{S}=$ indicates a molten salt 


\begin{tabular}{|c|c|c|c|}
\hline \multicolumn{4}{|c|}{ Symbols/Oznake } \\
\hline PAO & $\begin{array}{l}\text { - Polyalphaolefin } \\
\text { - Polialfa olefin }\end{array}$ & $\mathrm{H}$ & $\begin{array}{l}\text { - H value } \\
\text { - H značajka }\end{array}$ \\
\hline NPG & $\begin{array}{l}\text { - Neopentyl glicol } \\
\text { - neopentil glikol }\end{array}$ & $\Delta \mathrm{t}$ & $\begin{array}{l}\text { - cooling time } \\
\text { - vrijeme ohlađivanja }\end{array}$ \\
\hline TMP & $\begin{array}{l}\text { - trimethylol propane } \\
\text { - trimetilol propan }\end{array}$ & $v_{\mathrm{av}}$ & $\begin{array}{l}\text { - average cooling rate } \\
\text { - prosječna brzina ohlađivanja }\end{array}$ \\
\hline $\mathrm{PE}$ & $\begin{array}{l}\text { - pentaerythritol } \\
\text { - pentaeritritol }\end{array}$ & $\vartheta$ & $\begin{array}{l}\text { - Hardening temperature } \\
\text { - Temperatura kaljenja }\end{array}$ \\
\hline
\end{tabular}

$\mathrm{G}=$ indicates a gas

$\mathrm{F}=$ indicates products used for fluidized bed hardening

$\mathrm{K}=$ indicates all other cases.

These products are classified according to the phenomenon of tending to produce a vapour layer at the beginning of the immersion of a hot workpiece, which is called the Leidenfrost phenomenon. The vapour layer is created with quenching media whose boiling point is under the austenitization temperature such as water, oils, emulsions and polymer quenchants. The products without the Leidenfrost phenomenon are the media whose boiling point is above the austenitization temperature of steel such as molten salts and molten metals, gases and vacuum, such as fluidized beds and technical gases [3]. There are three stages of cooling process during immersion of the hot workpiece into a quenching medium which tends to produce a vapour layer. They are: a) the vapour layer stage, b) the boiling stage and c) the convection stage, as shown in Figure 1 [4].

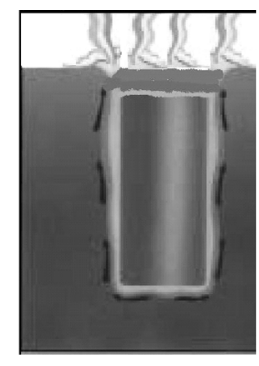

a - vapour layer stage / b - boiling stage / stadij sloja pare

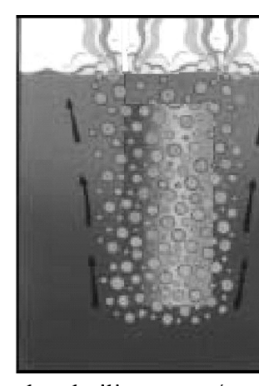

stadij ključanja

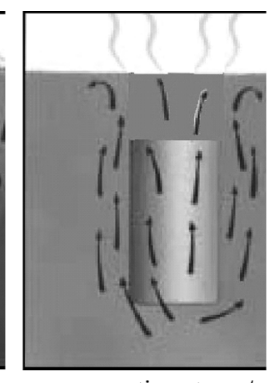

c - convection stage / stadij konvekcije
Figure 1. Stages of workpiece during cooling in quenching media with vapour layer

Slika 1. Stadiji ohlađivanja obratka u sredstvu za gašenje s parnim omotačem

The vapour layer stage (a) begins immediately after immersion of a hot workpiece into the quenchants. The high temperature of the workpiece forms the vapour layer which functions as an insulator preventing contact between the quenchant and the metal surface. The vapour layer has a low thermal conductivity which is the cause of the low cooling rate. The duration of this stage primarily depends on the quenching media. The temperature of the workpiece decreases depending on the quenchant and the workpiece geometry, the vapour layer becomes unstable and it disappears providing contact between the quenchant and the workpiece surface. Severe boiling (b) rapidly releases the heat and the colder fluid comes to the surface. The heat release occurs really fast from the surface. In this cooling stage maximum quenching rate is achieved and the temperature decrease reduces boiling. In the last cooling stage (c) when the temperature of the workpiece decreases under boiling point of the quenchant, the heat is released only by convection of the quenchant. Therefore, cooling at this stage can be considerably increased by the circulation of the quenchant [5].

\section{Properties and Composition of Quenchants}

The quenching media for heat treatment are hardening oils, emulsifying and synthetic fluids and water. Water is a severe quenching medium while oils cool considerably slower than water. The main disadvantage of oil is fire hazard and the main disadvantage of water is the weak corrosion protection. The positive properties of water and oil, as quenchants, are combined by the application of watermiscible medium.

The quenching media for heat treatment operation should be selected on the basis of its heat transfer characteristics, and also on the material quality to be quenched and the heat treatment process. Typically, quenching oils are classified into three groups: fast, accelerated and medium speed- conventional oils; and marquenching - hot oils [6].

Table 1 shows the oil classification which is used in heat treatment according to ISO 6743-14 norm in relation to the quenching procedure [2].

When selecting the quenchant or the raw material for production, attention must be paid not only to the technical requirements, but also to the requirements of the environmental protection and human safety [7]. Hardening oils contain base oil and additives. The base 
oil can be mineral (petroleum), synthetic or natural origin (vegetable or animal oils). High performance requirements for lubricants have led to an increased application of synthetic base oils such as polyalphaolefins or synthetic esters. Mineral base oils, naphtenic or paraffinic, are widely used because of their advantages in stability in comparison to natural oils, or lower prices in comparison to synthetic oils. In Table 2 the types and the most important properties of base oils according to API (American Petroleum Institute) classification are presented.
The function of additives is oxidation inhibition, foam inhibition, improved workpiece cleanness, improved cooling rate, etc. The basic physical and chemical properties of hardening oils are viscosity, boiling, fluidity, flash point, oxidation and thermal stability, volatility and washability. Viscosity, as one of the most important lubricant characteristics, present the internal friction criteria, whose work as resistance to the molecule position, change in the lubricant under the sheer stress. The viscosity depends on the temperature and the

Table 1. Classification of oils for heat treatment according to ISO 6743-14

Tablica 1. Klasifikacija ulja ta toplinsku obradbu prema ISO 6743-14

\begin{tabular}{|c|c|c|c|c|}
\hline $\begin{array}{l}\text { More specific application / } \\
\text { Određenija primjena }\end{array}$ & $\begin{array}{l}\text { Oil temperature at the time } \\
\text { of hardening / Temperatura } \\
\text { ulja u vrijeme kaljenja, }{ }^{\circ} \mathrm{C}\end{array}$ & $\begin{array}{c}\text { Product type and/or performance } \\
\text { requirements / Vrsta produkta i/ili } \\
\text { zahtjevana radna svojstva }\end{array}$ & $\begin{array}{c}\text { Symbol } \\
\text { / Simbol } \\
\text { ISO-L }\end{array}$ & $\begin{array}{l}\text { Remarks / } \\
\text { Napomene }\end{array}$ \\
\hline \multirow{2}{*}{$\begin{array}{l}\text { Cold hardening / Hladno } \\
\text { kaljenje }\end{array}$} & \multirow[b]{2}{*}{$\vartheta \leq 80$} & $\begin{array}{l}\text { Oil for normal hardening / } \\
\text { Mazivo za normalno kaljenje }\end{array}$ & UHA & \multirow[t]{9}{*}{$*$} \\
\hline & & $\begin{array}{l}\text { Oil for quick hardening / } \\
\text { Mazivo za brzo kaljenje }\end{array}$ & UHB & \\
\hline \multirow{2}{*}{$\begin{array}{l}\text { Semi hot hardening / } \\
\text { Poluhladno kaljenje }\end{array}$} & \multirow{2}{*}{$80<\vartheta \leq 130$} & $\begin{array}{l}\text { Oil for normal hardening / } \\
\text { Mazivo za normalno kaljenje }\end{array}$ & $\mathrm{UHC}$ & \\
\hline & & $\begin{array}{l}\text { Oil for quick hardening / } \\
\text { Mazivo za brzo kaljenje }\end{array}$ & UHD & \\
\hline \multirow{2}{*}{$\begin{array}{l}\text { Hot hardening / Vruće } \\
\text { kaljenje }\end{array}$} & \multirow{2}{*}{$130<\vartheta \leq 200$} & $\begin{array}{l}\text { Oil for normal hardening / } \\
\text { Mazivo za normalno kaljenje }\end{array}$ & UHE & \\
\hline & & $\begin{array}{l}\text { Oil for quick hardening / } \\
\text { Mazivo za brzo kaljenje }\end{array}$ & UHF & \\
\hline \multirow{2}{*}{$\begin{array}{l}\text { Very hot hardening / } \\
\text { Jako vruće kaljenje }\end{array}$} & \multirow{2}{*}{$200<\vartheta \leq 310$} & $\begin{array}{l}\text { Oil for normal hardening / } \\
\text { Mazivo za normalno kaljenje }\end{array}$ & UHG & \\
\hline & & $\begin{array}{l}\text { Oil for quick hardening / } \\
\text { Mazivo za brzo kaljenje }\end{array}$ & UHH & \\
\hline $\begin{array}{l}\text { Vacuum hardening / } \\
\text { Vakuumsko kaljenje }\end{array}$ & & & UHV & \\
\hline $\begin{array}{l}\text { Other cases / } \\
\text { Ostali slučajevi }\end{array}$ & & & UHK & \\
\hline
\end{tabular}

*Remarks: Certain oils may be easily eliminated by washing with water. This characteristic is brought about by the presence of emulsifiers in the formula. The oils are then known as "washable".

Table 2. API Classification of base oils and basic properties

Tablica 2. API klasifikacija baznih ulja i osnovna svojstva

\begin{tabular}{|l|c|c|c|}
\hline \multicolumn{1}{|c|}{ API GROUP / API skupina } & $\begin{array}{c}\text { Saturated hydrocarbons / Zasićeni } \\
\text { ugljikovodici, \% }\end{array}$ & $\begin{array}{c}\text { Sulphur / Sumpor, \% } \\
\text { index / Indeks } \\
\text { viskoznosti }\end{array}$ \\
\hline $\begin{array}{l}\text { GROUP I, solvent-refinement / Skupina I, } \\
\text { rafiniranje otapala }\end{array}$ & below / niže od 90 & $>0.03$ & $80-120$ \\
\hline $\begin{array}{l}\text { GROUP II, hydrotreatment / } \\
\text { Skupina II, hidrotretiranje }\end{array}$ & $>/=90$ & $</=0.03$ & $80-120$ \\
\hline $\begin{array}{l}\text { GROUP III, deep hydrotreatment / wax } \\
\text { isomerization / SKupina III, dubinsko } \\
\text { hidrotretiranje / izomerizacija voskom }\end{array}$ & $>$ / 90 & $120+$ \\
\hline $\begin{array}{l}\text { GROUP IV, polyalphaolefins (PAO), } \\
\text { polymerization, hydrogenation / SKupina } \\
\text { IV, polialfaolefini (PAO), polimerizacija, } \\
\text { hidrogenizacija }\end{array}$ & $\begin{array}{l}\text { defined formula / definirana formula } \\
\text { R-CHCH3-/CH2-CHR/X-H }\end{array}$ & - & $130+$ \\
\hline GROUP V / SKupina V & $\begin{array}{l}\text { All other base oils (including those synthetic) / Sva ostala bazna ulja } \\
\text { (uključujući sintetička) }\end{array}$ \\
\hline
\end{tabular}


pressure. The cooling rate depends on the viscosity. The emulsifying fluids contain base oil and a greater amount of surface-active substances in order to produce a stable emulsion and corrosion protection. The synthetic agents do not contain an oil component but they contain surfaceactive substances, corrosion inhibitors, high molecular contents - polymers and other substances. There are numerous composition possibilities but environmental and safety requirements have a strong influence on the additive selection. In this type of industrial oils an important restriction is placed on barium additives which have been in use for years and now they should be replaced [5].

\section{Experimental}

\subsection{Test samples of quenchants}

Test samples are prepared for examination of the influence of oil composition on cooling properties in heat treatment processes. Samples of test oils consist of different types of base oils and additives. As base oil we use SN-solvent rafined mineral oil paraffinic, HC5catalitically hydroisomerized and dewaxed hydrocarbon,
PAO-polyalphaolefine, isoparafinic synthetic fluid, hydrogenated $\mathrm{C} 10$ oligomer, and 3 types of ester oils. Those are two synthetic esters SE1-with flash point of $308{ }^{\circ} \mathrm{C}$, SE2-saturated polyol ester (NPG/TMP/PE) and vegetable oil, rape seed oil refined and additionally stabilised with additive Ad2. All compositions are less harmful to the environment and humans because they do not contain barium compounds. Functional test additive contains sodium and calcium sulfonates, AdS. Table 3 presents compositions of test samples of oils.

In this study examination of physical-chemical properties and also cooling characteristics of new quenching oils with different compositions have been done. Cooling curves for different compositions have been evaluated according to ISO 9950 standard.

\subsection{Test methods for determination of physical and chemical properties of test medium}

The most important properties of quenching fluids that should be determined are: viscosity, flash point, boiling point, oxidation and thermo stability, fluidity, volatility and, in certain applications, washability. Viscosity is measured by the standard ISO 3104 (ASTM D 445)

Table 3. Test quenching oil samples and their composition

Tablica 3. Oznake i sastav ispitivanih ulja za gašenje

\begin{tabular}{|c|c|c|c|}
\hline Sample No. / Br. uzorka & $\begin{array}{c}\text { Viscosity grade / } \\
\text { Klasa viskoznosti }\end{array}$ & $\begin{array}{l}\text { Grade of oil / Klasa ulja, } \\
\text { API skupina, API GROUP }\end{array}$ & Composition / Sastav \\
\hline 47 & 32 & Base oil / Bazno ulje, I & Mineral oil paraffinic, SN 150 \\
\hline 34 & & Additive / Aditiv, $0.5 \%$ & + AdS \\
\hline 35 & & Additive / Aditiv, $2 \%$ & $+\mathrm{AdS}$ \\
\hline 36 & & Additive / Aditiv, $3 \%$ & $+\mathrm{AdS}$ \\
\hline 48 & 48 & Base oil / Bazno ulje, IV & PAO, polyalphaolefine / PAO, polialfaolefin \\
\hline 37 & & Additive / Aditiv, $0.5 \%$ & $+\mathrm{AdS}$ \\
\hline 38 & & Additive / Aditiv, $2 \%$ & $+\mathrm{AdS}$ \\
\hline 39 & & Additive / Aditiv, $3 \%$ & $+\mathrm{AdS}$ \\
\hline 49 & 25 & Base oil / Bazno ulje, III & $\begin{array}{l}\text { HC5, hydroisomerized / HC5, } \\
\text { hidroizomerizirano }\end{array}$ \\
\hline 40 & & Additive / Aditiv, $0.5 \%$ & + AdS \\
\hline 41 & & Additive / Aditiv, $2 \%$ & $+\mathrm{AdS}$ \\
\hline 42 & & Additive / Aditiv, $3 \%$ & + AdS \\
\hline 46 & 37 & Base oil / Bazno ulje, V-V & Vegetable oil / Biljno ulje \\
\hline 31 & & Additive / Aditiv, $0.5 \%$ & + AdS \\
\hline 32 & & Additive / Aditiv, $2 \%$ & $+\mathrm{AdS}$ \\
\hline 33 & & Additive / Aditiv, $3 \%$ & + AdS \\
\hline 50 & 37 & Base oil / Bazno ulje, V-Vst & $\begin{array}{l}\text { Vegetable oil, stabilised / Biljno ulje, } \\
\text { stabilizirano }\end{array}$ \\
\hline 43 & & Additive / Aditiv, $0.5 \%$ & $+\mathrm{AdS}+0.25 \% \mathrm{Ad} 2$ \\
\hline 44 & & Additive / Aditiv, $2 \%$ & $+\mathrm{AdS}+0.25 \% \mathrm{Ad} 2$ \\
\hline 45 & & Additive / Aditiv, $3 \%$ & $+\mathrm{AdS}+0.25 \% \mathrm{Ad} 2$ \\
\hline 51 & 45 & $\begin{array}{l}\text { Base oil / Bazno ulje, } \\
\text { V-SE1 }\end{array}$ & SE1, Synthetic ester / Sintetički ester 1 \\
\hline 52 & & $\begin{array}{l}\text { Base oil / Bazno ulje, } \\
\text { V-SE2 }\end{array}$ & SE2, Synthetic ester / Sintetički ester 2 \\
\hline
\end{tabular}


using a common viscometer at the standard temperatures of $100{ }^{\circ} \mathrm{C}$ and $40{ }^{\circ} \mathrm{C}$ in $\mathrm{mm}^{2} \mathrm{~s}^{-1}$ [8]. The viscosity of quenching oils is a very important property for the quenching hardening process. Viscous oil will produce a more stable vapour blanket, consequently slowing down the cooling rate. The flash point of oil, by definition, is the lowest temperature at which the application of a flame causes the vapour above the oil to ignite and is determined according to ISO 2592. The appearance and colour of oils can be determined by several methods. The ASTM Colour determination by the standard ASTM D 1500 (ISO 2049) is commonly used. A test portion of the oil is viewed under an artificial daylight source and the colour is compared with the colour of glass disks ranging in value from 0.5 to 8.0. Appearance also can be determined visually. Oxidation stability describes the oxidation of quenching oils as a result from a chemical reaction between the molecules of the oil and the oxygen from the atmosphere. The rate of oil oxidation increases

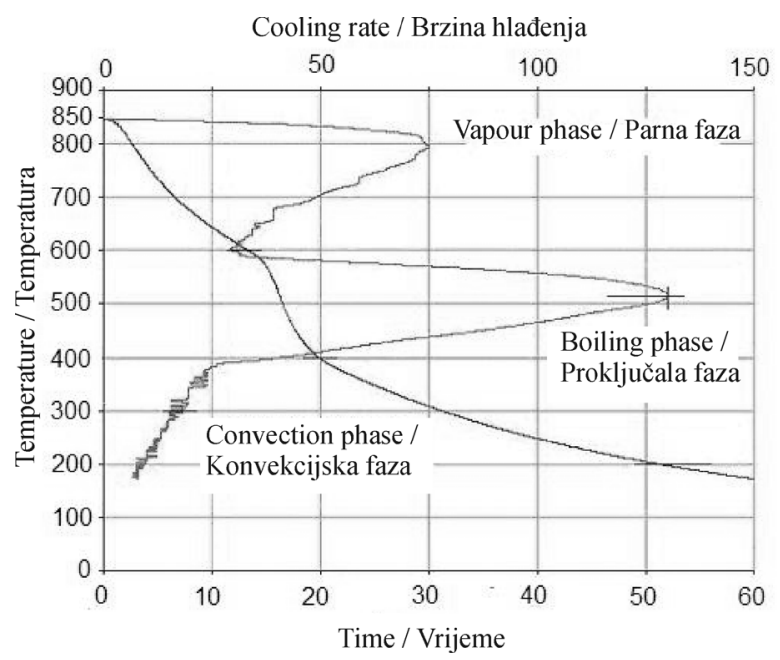

Figure 2. Characteristic cooling curve (temperature-time and temperature-cooling rate) [10]

Slika 2. Karakteristična krivulja ohlađivanja (temperaturavrijeme i temperatura-brzina ohlađivanja) greatly as temperature increases. The products of oxidation are complex in nature and include acidic and insoluble materials, which can affect the quenching rate and may cause corrosion, staining and sludge formation. Thermal stability is a property that points out the thermal degradation of quenching oil. Degradation occurs when oil molecules split or crack due to the intense localized heat generated during the workpiece quenching. The results of such reactions manifest themselves as carbon deposits and lighter more volatile materials. These potentially contamination effects can be minimized by base oil selection, additive technology and good system maintenance. The thermal and oxidation stabilities of oils can be measured by several methods. We used an internal method that is a modification of ASTM D 2160. Samples in open cups are heated for 40 hours at temperatures of $170^{\circ} \mathrm{C}$ and $200^{\circ} \mathrm{C}$. Physical and chemical properties of test oils are measured before and after the treatment. The properties that are examined are: acid number, kinematic viscosity at $40{ }^{\circ} \mathrm{C}$, ASTM colour, refractive index and sludge formation.

The test probe diameter $12.5 \mathrm{~mm}$ and length $60 \mathrm{~mm}$ was used for testing the cooling curve according to ISO 9950:1995 method [9]. The probe is made of Nickel alloy INCONEL 600. In the centre of the probe $\mathrm{NiCr} /$ $\mathrm{NiAl}$ thermocouple is positioned. The thermocouple is connected to a PC in order to register the needed values: temperature and time.

\section{Test results and discussion}

Table 4 shows the physical and chemical properties of the test base fluids and the appropriate standard test methods. The test results show that test fluids have different properties. Formulations of 45 viscosity grade mixed with functional additive is turbid, so the mixing of test fluids is stopped and another additive should be found for that base fluid. All other formulations are stable due to component compatibility.

Table 4. Physical-chemical properties of test base oils and methods

Tablica 4. Fizikalno kemijska svojstva i metode ispitivanja ispitivanih baznih ulja

\begin{tabular}{|c|c|c|c|c|c|}
\hline $\begin{array}{l}\text { BASE OILS / Bazno ulje } \\
\text { API GROUP-type / API skupina - vrsta }\end{array}$ & I-SN 150 & III-HC5 & IV-PAO & \begin{tabular}{|c|} 
V-VEGETABLE / \\
V biljna \\
\end{tabular} & V-SE1 \\
\hline $\begin{array}{l}\text { Viscosity / Viskoznost, } 40^{\circ} \mathrm{C}, \mathrm{mm}^{2} / \mathrm{s} \text {, } \\
\text { ISO } 3104\end{array}$ & 32 & 24.4 & 48 & 37 & 45.9 \\
\hline $\begin{array}{l}\text { Density / Gustoća, } 15^{\circ} \mathrm{C}, \mathrm{g} / \mathrm{cm}^{3} \text {, } \\
\text { ISO } 3675\end{array}$ & 0.872 & 0.838 & 0.832 & 0.878 & 0.919 \\
\hline $\begin{array}{l}\text { Flash point / Plamište, }{ }^{\circ} \mathrm{C}, \mathrm{min}, \\
\text { ISO } 2592\end{array}$ & 200 & 230 & 255 & 300 & 308 \\
\hline $\begin{array}{l}\text { Color and appearance, Visually / } \\
\text { Boja i izgled, vizuelno }\end{array}$ & $\begin{array}{l}\text { yellow clear oil } \\
\text { / Žuto prozirno } \\
\text { ulje } \\
\end{array}$ & $\begin{array}{l}\text { clear colorless } \\
\text { / prozirno i } \\
\text { bezbojno } \\
\end{array}$ & $\begin{array}{l}\text { clear colorless } \\
\text { / prozirno i } \\
\text { bezbojno } \\
\end{array}$ & $\begin{array}{l}\text { yellow clear oil / } \\
\text { Žuto prozirno ulje }\end{array}$ & $\begin{array}{l}\text { yellow clear oil } \\
\text { / Žuto prozirno } \\
\text { ulje } \\
\end{array}$ \\
\hline $\begin{array}{l}\text { Color and appearance, Visually mixture } \\
\text { with additives / Boja i izgled, vizuelno } \\
\text { mješavina s aditivima }\end{array}$ & $\begin{array}{l}\text { yellow clear oil } \\
\text { / Žuto prozirno } \\
\text { ulje }\end{array}$ & $\begin{array}{l}\text { clear colorless } \\
\text { / prozirno i } \\
\text { bezbojno }\end{array}$ & $\begin{array}{l}\text { clear colorless } \\
\text { / prozirno i } \\
\text { bezbojno }\end{array}$ & $\begin{array}{l}\text { yellow clear oil / } \\
\text { Žuto prozirno ulje }\end{array}$ & $\begin{array}{c}\text { turbid, } \\
\text { separation / } \\
\text { zamućeno, } \\
\text { separacija }\end{array}$ \\
\hline
\end{tabular}




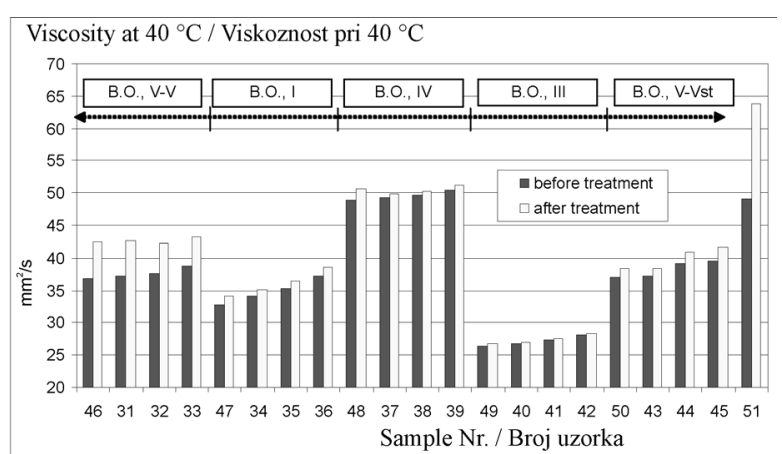

Figure 3. The results of viscosity determination at $40{ }^{\circ} \mathrm{C}$ of test oils before and after thermal treatment

Slika 3. Rezultati određivanja viskoznosti pri $40{ }^{\circ} \mathrm{C}$ ispitivanih ulja prije i nakon termičke obrade

For the thermal stability determination of test oils we treated oils under high temperature conditions (at $170{ }^{\circ} \mathrm{C}$ ) for 30 hours according to the modified ASTM D 2160 method. Physical and chemical properties of test oils are measured before and after treatment. Figure 3 shows the results of the viscosity determination of test oils (ISO 3104) before and after the treatment at high temperatures. Viscosities of all samples are increased after high temperature treatment compared to the start values. A higher additive content results in lower values of viscosity increase. The viscosity of base oil is increased faster than the viscosity of oils with additives. The highest viscosity increase showed Base oil, V-SE1, after that vegetable oil Base oil, V-V nonstabilised samples 46, 31, 32 and 33. The best results shoved base oil from API group III, HC5, hydroisomerized hydrocarbon.

The results of determination of sample colors, Table 5 , and comparison before and after treatment shows that the highest degradations occurred in formulations with Base oil, I group. After that Base oil, III group, samples 49, 40, 41 and 42 follow. Formulations based on vegetable base oils showed almost the same results. Also it is obvious that degradation is lower at lower additive quantity. Table 6 gives the results of the acid number determination of tested oils (ISO 6618). It is obvious that in most formulations there is an increase of acid values. In formulations based on vegetable base oil, values are higher compared to others. Also we examined corrosiveness of oils before and after thermal treatment by corrosion test on copper plate, according to ASTM D 130 (ISO 2160). The results are that corrosion properties of all oils showed

Table 5. The results of color determination of test oils before and after thermal treatment

Tablica 5. Rezultati određivanja boje ispitivanih ulja prije i nakon termičke obrade

\begin{tabular}{|c|c|c|c|c|c|}
\hline $\begin{array}{c}\text { Sample } \\
\text { No. / Br. } \\
\text { uzorka }\end{array}$ & $\begin{array}{l}\text { Formula / } \\
\text { Formula }\end{array}$ & $\begin{array}{c}\text { Color value } \\
\text { before } \\
\text { treatment / } \\
\text { Vrijednost } \\
\text { boje prije } \\
\text { obrade }\end{array}$ & $\begin{array}{c}\text { Color value } \\
\text { after } \\
\text { treatment / } \\
\text { Vrijednost } \\
\text { boje nakon } \\
\text { obrade }\end{array}$ & $\begin{array}{c}\text { Color } \\
\text { Increase, } \\
\text { grades } \\
\text { / Porast } \\
\text { vrijednosti } \\
\text { boje, u } \\
\text { razredima }\end{array}$ & $\begin{array}{l}\text { Appearance, sediment, visually, after treatment / } \\
\text { Izgled, sedimenti, vizualno nakon obrade }\end{array}$ \\
\hline 46 & Base oil, V-V & 0.5 & 1.0 & 1 & light yellow clear, no / svijetlo-žuto, bez \\
\hline 31 & Additive, $0.5 \%$ & $<1.5$ & 2.0 & $>1$ & yellow clear, no / prozirno žuto, bez \\
\hline 32 & Additive, $2 \%$ & 1.5 & 4.5 & 5 & dark yellow clear, no / tamno-žuto prozirno, ne \\
\hline 33 & Additive, $3 \%$ & 2.0 & 5.0 & 6 & brown clear, no / smeđ-žuto, bez \\
\hline 47 & Base oil, I & $<0.5$ & $>8.0$ & $>16$ & $\begin{array}{l}\text { dark brown - black turbid, black sediment / tamno smeđe-crno } \\
\text { zamućeno, crni sediment }\end{array}$ \\
\hline 34 & Additive, $0.5 \%$ & 1.0 & 4.5 & 7 & dark yellow, clear, no / tamno-žuto prozirno, bez \\
\hline 35 & Additive, $2 \%$ & 1.5 & 5.0 & 7 & brown clear, no / smeđ-žuto, bez \\
\hline 36 & Additive, $3 \%$ & $<2.0$ & 7.0 & $<10$ & $\begin{array}{l}\text { dark brown clear, no / tamno smeđe-crno zamućeno, crni } \\
\text { sediment }\end{array}$ \\
\hline 48 & Base oil, IV & 0.0 & 0.5 & 1 & light yellowish clear, no / vijetlo-žućkasto prozirno, bez \\
\hline 37 & Additive, $0.5 \%$ & $<0.5$ & $<1.0$ & 1 & light yellow clear, no / svijetlo-žuto, bez \\
\hline 38 & Additive, $2 \%$ & $<1.5$ & 5.0 & 7 & brown clear, no / smeđ-žuto, bez \\
\hline 39 & Additive, $3 \%$ & 1.5 & 6.5 & 10 & $\begin{array}{l}\text { dark brown clear, no / tamno smeđe-crno zamućeno, crni } \\
\text { sediment }\end{array}$ \\
\hline 49 & Base oil, III & 0.0 & 1.5 & 3 & light yellow clear, no / svijetlo-žuto, bez \\
\hline 40 & Additive, $0.5 \%$ & $<1.0$ & $<2.0$ & 2 & yellow clear, no / prozirno žuto, bez \\
\hline 41 & Additive, $2 \%$ & $<1.5$ & 5.0 & 7 & brown clear, no / smeđ-žuto, bez \\
\hline 42 & Additive, $3 \%$ & $<2.0$ & 6.5 & $>9$ & $\begin{array}{l}\text { dark brown clear, no / tamno smeđe-crno zamućeno, crni } \\
\text { sediment }\end{array}$ \\
\hline 50 & Base oil, V-Vst & 0.5 & 1.0 & 1 & light yellow clear, no / svijetlo-žuto, bez \\
\hline 43 & Additive, $0.5 \%$ & $<1.5$ & 2.5 & $>2$ & yellow clear, no / prozirno žuto, bez \\
\hline 44 & Additive, $2 \%$ & 2.0 & 4.5 & 5 & dark yellow clear, no / tamno-žuto prozirno, bez \\
\hline 45 & Additive, $3 \%$ & 2.5 & 5.0 & 5 & brown clear, no / smeđ-žuto, bez \\
\hline 51 & Base oil V-SE1 & 0.5 & 1.5 & 2 & light yellow clear, no / svijetlo-žuto, bez \\
\hline
\end{tabular}


Table 6. The results of test oils' acid numbers and corrosion determination at thermal treatment

Tablica 6. Rezultati određivanja kiselinskog broja i korozije ispitivanih ulja prije i nakon grijanja

\begin{tabular}{|c|c|c|c|c|}
\hline $\begin{array}{l}\text { Sample } \\
\text { No. / Broj } \\
\text { uzorka }\end{array}$ & Composition / Sastav & $\begin{array}{c}\text { Acid number, } \\
\text { mgKOH/g, } \\
\text { before treatment / } \\
\text { Kiselost, } \mathrm{mgKOH} / \mathrm{g}, \\
\text { prije obrade }\end{array}$ & $\begin{array}{c}\text { Acid number, } \\
\mathrm{mgKOH} / \mathrm{g}, \\
\text { after treatment } / \\
\text { Kiselost, } \mathrm{mgKOH} / \mathrm{g}, \\
\text { nakon obrade }\end{array}$ & $\begin{array}{c}\text { Corrosion to } \mathrm{Cu}, \\
100^{\circ} \mathrm{C}, 3 \mathrm{~h}, \text { before/after } \\
\text { treatment / Korozivnost za Cu, } \\
100^{\circ} \mathrm{C}, 3 \mathrm{~h}, \text { prije/nakon obrade }\end{array}$ \\
\hline 46 & Base oil / Bazno ulje, V-V & 0 & 0.40 & $1 \mathrm{a} / 1 \mathrm{a}$ \\
\hline 31 & Additive / Aditivi, $0.5 \%$ & 0 & 0.74 & $1 \mathrm{a} / 1 \mathrm{a}$ \\
\hline 32 & Additive / Aditivi, $2 \%$ & 0 & 0.78 & $1 \mathrm{a} / 1 \mathrm{a}$ \\
\hline 33 & Additive / Aditivi, $3 \%$ & 0 & 0.86 & $1 \mathrm{a} / 1 \mathrm{a}$ \\
\hline 47 & Base oil / Bazno ulje, I & 0 & 0.08 & $1 \mathrm{a} / 1 \mathrm{a}$ \\
\hline 34 & Additive / Aditivi, $0.5 \%$ & 0 & 0.15 & $1 \mathrm{~b} / 1 \mathrm{~b}$ \\
\hline 35 & Additive / Aditivi, $2 \%$ & 0 & 0.06 & $1 \mathrm{~b} / 1 \mathrm{~b}$ \\
\hline 36 & Additive / Aditivi, $3 \%$ & 0 & 0.01 & $1 \mathrm{~b} / 1 \mathrm{~b}$ \\
\hline 48 & Base oil / Bazno ulje, IV & 0 & 0.27 & $1 \mathrm{a} / 1 \mathrm{a}$ \\
\hline 37 & Additive / Aditivi, $0.5 \%$ & 0 & 0.16 & $1 \mathrm{~b} / 1 \mathrm{~b}$ \\
\hline 38 & Additive / Aditivi, $2 \%$ & 0 & 0.04 & $1 \mathrm{~b} / 1 \mathrm{~b}$ \\
\hline 39 & Additive / Aditivi, $3 \%$ & 0 & 0.06 & $1 \mathrm{~b} / 1 \mathrm{~b}$ \\
\hline 49 & Base oil / Bazno ulje, III & 0 & 0.54 & $1 \mathrm{a} / 1 \mathrm{a}$ \\
\hline 40 & Additive / Aditivi, $0.5 \%$ & 0 & 0.13 & $1 \mathrm{~b} / 1 \mathrm{~b}$ \\
\hline 41 & Additive / Aditivi, $2 \%$ & 0 & 0.08 & $1 \mathrm{~b} / 1 \mathrm{~b}$ \\
\hline 42 & Additive / Aditivi, $3 \%$ & 0 & 0.03 & $1 \mathrm{~b} / 1 \mathrm{~b}$ \\
\hline 50 & Base oil / Bazno ulje, V-Vst & 0 & 0.00 & $1 \mathrm{a} / 1 \mathrm{a}$ \\
\hline 43 & Additive / Aditivi, $0.5 \%$ & 0 & 0.42 & $1 \mathrm{a} / 1 \mathrm{a}$ \\
\hline 44 & Additive / Aditivi, $2 \%$ & 0 & 0.79 & $1 \mathrm{a} / 1 \mathrm{a}$ \\
\hline 45 & Additive / Aditivi, $3 \%$ & 0 & 0.86 & $1 \mathrm{a} / 1 \mathrm{a}$ \\
\hline 51 & Base oil / Bazno ulje V-SE1 & 0 & 0.87 & $1 \mathrm{a} / 1 \mathrm{a}$ \\
\hline
\end{tabular}

no changes to the start values. Formulations with mineral base oil SN 150 and PAO have higher corrosion values in comparison to the other formulations.

In Figures 4, 5, 6 and 7 the results of the measurement of test oils cooling properties are shown. Test oils are grouped according to their base oil composition and also additive added. Figure 4 shows temperature vs. time plots for the test probe cooled in the all base oils. Figure 4, 5 and 6 show cooling properties measurement results for all hydrocarbon tested medium. On Figure 7 cooling properties of tested medium based on vegetable oil are presented.

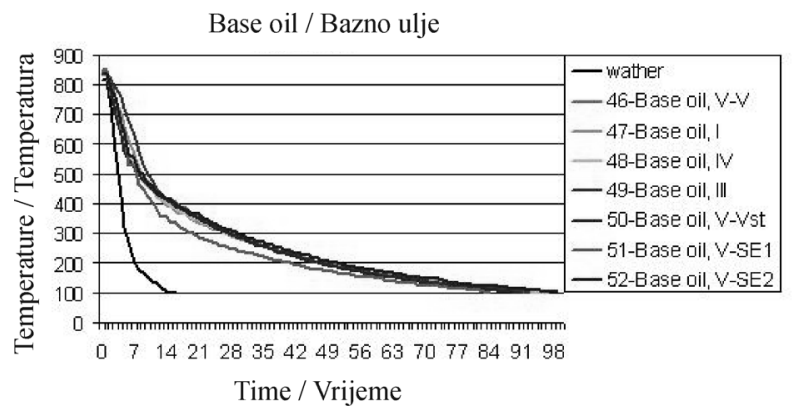

Figure 4. Temperature vs. time plots for the test probe cooled in the tested oils, Samples 46 - 52

Slika 4. Dijagramski prikaz promjene temperatura-vrijeme ispitivanih ulja uzoraka $46-52$
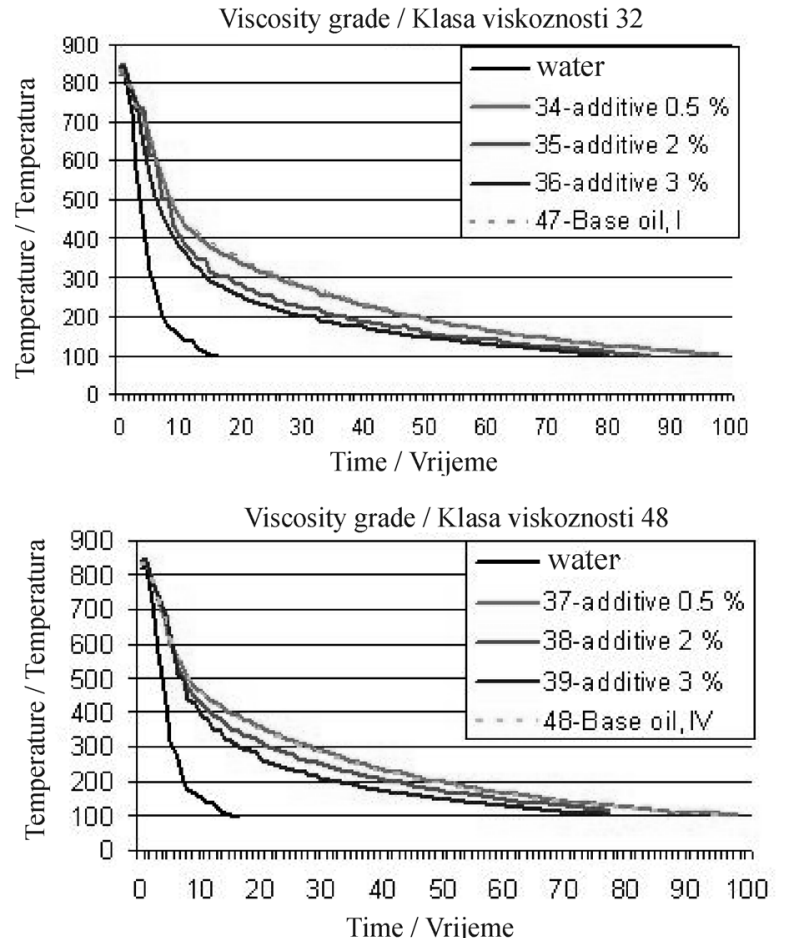

Figure 5. Temperature vs. time plots for the test probe cooled in the tested base-oil viscosity grade 32 and 48

Slika 5. Dijagramski prikaz promjene temperatura-vrijeme ispitivanih baznih ulja viskozitetne gradacije 32 i 48 

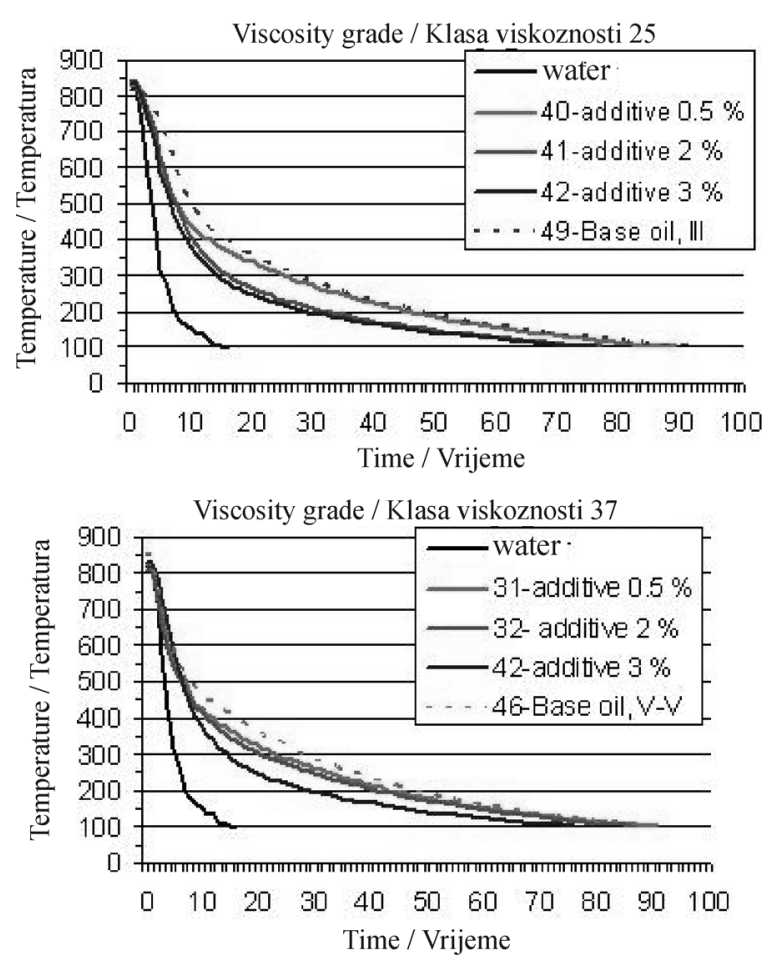

Figure 6. Temperature vs. time plots for the test probe cooled in the tested base-oil viscosity grade 25 and 37

Slika 6. Dijagramski prikaz promjene temperatura-vrijeme ispitivanih baznih ulja viskozitetne gradacije 25 i 37

Table 7. The cooling rates and the $\mathrm{H}$ value test results of tested fluids

Tablica 7. Rezultati određivanja brzine ohlađivanja i značajke $\mathrm{H}$ ispitivanih sredstava

\begin{tabular}{|c|c|c|c|}
\hline Sample No. & $\Delta \mathrm{t}, \mathrm{s}$ & $v_{\mathrm{av}}{ }^{\circ} \mathrm{C} / \mathrm{s}$ & $\mathrm{H}$ \\
\hline 47 & 23,0 & 17,3 & 0,15 \\
\hline 34 & 20,5 & 19,5 & 0,17 \\
\hline 35 & 13,0 & 30,0 & 0,27 \\
\hline 36 & 10,5 & 38,0 & 0,33 \\
\hline 48 & 23,5 & 17,0 & 0,14 \\
\hline 37 & 24,8 & 16,1 & 0,12 \\
\hline 38 & 17,8 & 22,5 & 0,19 \\
\hline 39 & 12,5 & 32,0 & 0,28 \\
\hline 49 & 23,0 & 17,4 & 0,15 \\
\hline 40 & 21,5 & 18,6 & 0,16 \\
\hline 41 & 12,0 & 33,3 & 0,29 \\
\hline 42 & 10,0 & 40,0 & 0,35 \\
\hline 46 & 25,0 & 16,0 & 0,14 \\
\hline 31 & 20,5 & 19,5 & 0,17 \\
\hline 32 & 17,5 & 22,8 & 0,20 \\
\hline 33 & 14,5 & 27,6 & 0,24 \\
\hline 50 & 24,0 & 16,6 & 0,14 \\
\hline 43 & 23,0 & 17,4 & 0,15 \\
\hline 44 & 14,5 & 27,6 & 0,24 \\
\hline 45 & 12,7 & 31,5 & 0,28 \\
\hline 51 & 26,5 & 15,0 & 0,13 \\
\hline 52 & 25,5 & 15,6 & 0,12 \\
\hline
\end{tabular}

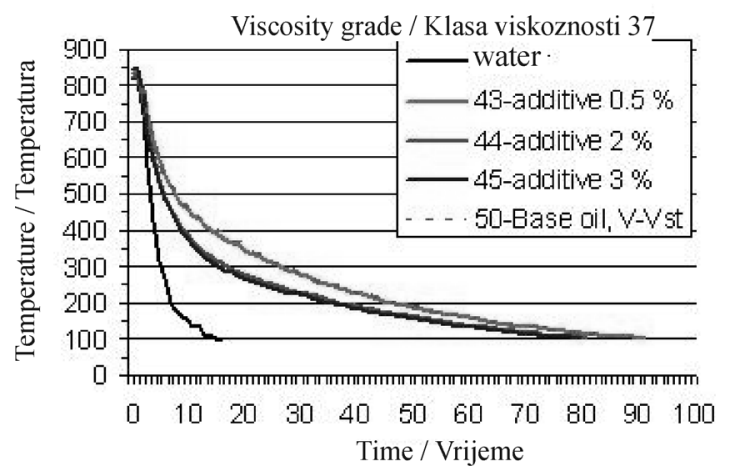

Figure 7. Temperature vs. time plots for the test probe cooled in the tested base-oil viscosity grade 37

Slika 7. Dijagramski prikaz promjene temperatura-vrijeme ispitivanih baznih ulja viskozitetne gradacije 37

The diagrams gave us the average cooling rates $v_{a v}$ $\left({ }^{\circ} \mathrm{C} / \mathrm{s}\right)$ for the temperature interval 700 to $300\left({ }^{\circ} \mathrm{C}\right.$, and the $\mathrm{H}$ values of particular test samples have been determined. The values are shown in Table 7.

\section{Conclusion}

Based on the latest environmental and safety requirements and development trends we have made heat treatment oils with an adequate composition that they are less harmful as they do not contain harmful additives with barium. We prepared several grades of test oils with different types of base oil, mineral, synthetic and natural oil.

The average cooling rates and the $\mathrm{H}$ values according to ISO 9950 method are determined for all samples. The results of the tested samples show that fluids of different composition significantly change the characteristics which are important for the cooling capacity.

Formulations based on rape-seed oil are natural oils from renewable source, but are less stable than other formulations. In addition, we prepared the quenching oil of viscosity grade 37 , based on vegetable oils, improved with additives.

From these examination results, it is obvious that cooling characteristics are dependent on the composition of oil. Cooling characteristics are changed by adding different types of base oils. They also depend on the concentration of additives. By adding additives, the cooling rate is increased as well as the $\mathrm{H}$-value.

Based on these results, specific oil compositions can be used in steel quenching processes in accordance with specific quality requirements of a workpiece. 


\section{REFERENCES}

[1] LIŠČIĆ, B.; STUPNIŠEK, M.; CAJNER, F.; FILETIN, T.: Toplinska obrada, Praktikum FSB, Zagreb 1991.

[2] ISO 6743 - 14, Lubricants, industrial oils and related products (class L) - Classification- Part 14: Family U (Heat treatment), Geneve 1994.

[3] Drayton PACS Quenchmaster Reports, www.dpacs. co.uk

[4] MAC KENZIE, D. S.: Selection of Quench Oils, Houghton International, Valley Forge PA

[5] BEITZ, T.: Substitution of Quenching oils with high risk of fire to Waterbased Quenchants without Flames and Fumes, 15th IFHTSE \& 20 SMT, Vienna 2006.
[6] CHAN KA MAN, C.: Heat Treatment of Mould, Feb 2001., rpdrc.ic.polyu.edu.hk /content/hot_metal process/heat_treatment1.htm

[7] ROCKER, M.: VKIS-VSI-Komponentenliste fuer KSS nach DIN 51385, 13th International Colloquium Tribology TAE, Stuttgart 2002.

[8] ASTM and ISO standards for determination of fluids physical- chemical properties

[9] ISO 9950 Industrial quenching oils - Determination of cooling characteristics-Nickel-alloy probe test method, Geneve 1995.

[10] FELDE, I.; RETI, T., SEGERBERG, S.; BODIN, J.; TOTTEN, G.E.: Characterization of Quenching Performance by using Computerized Procedures and Data Base of Heat Treatment Processes, 8th Seminar of the IFHTSE, Dubrovnik 2001. 